\title{
Religion and the risk of suicide: longitudinal study of over 1 million people
}

Dermot O'Reilly and Michael Rosato

\section{Background}

Durkheim's seminal historical study demonstrated that religious affiliation reduces suicide risk, but it is unclear whether this protective effect persists in modern, more secular societies.

\section{Aims \\ To examine suicide risk according to Christian religious affiliation and by inference to examine underlying mechanisms for suicide risk. If church attendance is important, risk should be lowest for Roman Catholics and highest for those with no religion; if religiosity is important, then 'conservative' Christians should fare best. \\ Method \\ A 9-year study followed 1106104 people aged 16-74 years at the 2001 UK census, using Cox proportional hazards models adjusted for census-based cohort attributes. \\ Results \\ In fully adjusted models analysing 1119 cases of suicide Roman Catholics, Protestants and those professing no}

religion recorded similar risks. The risk associated with conservative Christians was lower than that for Catholics $(\mathrm{HR}=0.71,95 \% \mathrm{Cl} 0.52-0.97)$.

\section{Conclusions}

The relationship between religious affiliation and suicide established by Durkheim may not pertain in societies where suicide rates are highest at younger ages. Risks are similar for those with and without a religious affiliation, and Catholics (who traditionally are characterised by higher levels of church attendance) do not demonstrate lower risk of suicide. However, religious affiliation is a poor measure of religiosity, except for a small group of conservative Christians, although their lower risk of suicide may be attributable to factors such as lower risk behaviour and alcohol consumption.

\section{Declaration of interest}

None.

\section{Copyright and usage}

(c) The Royal College of Psychiatrists 2015.
The relationship between religion and suicide was first established in Emile Durkheim's 19th-century seminal treatise. ${ }^{1}$ This has since been corroborated in different countries, ${ }^{2,3}$ most recently by Swiss researchers who used a year 2000 census-based cohort study to show that such risk patterns still persisted, with risk highest for those with no religious affiliation, lowest for Roman Catholics and intermediate for Protestants. ${ }^{4}$ Why religion should exhibit this protective effect is less clear: Durkheim attributed it to the sense of community that arises from active church membership, with attendance the most commonly cited attribute. ${ }^{5}$ Others, however, emphasise the moral and religious objections to suicide, ${ }^{6,7}$ although Durkheim was at pains to rule this out as an explanation. ${ }^{1}$ Perhaps a more pertinent question is why, given increasing societal secularisation, ${ }^{8,9}$ does the relationship between religion and suicide still seem to persist? Increasing secularisation is also evident in Switzerland, where by the end of the 1990s nonpractising Christians made up almost half the population, ${ }^{10}$ and a further $11 \%$ cited no religious affiliation. ${ }^{11}$ This has led many social researchers, including some in Switzerland, to conclude that affiliation bears little correspondence to religious belief or practice but is more likely to reflect a diverse set of traditions or social convenience. ${ }^{12}$

This study examines the relationship between religious affiliation and suicide risk in Northern Ireland, a country with high levels of professed religiosity and church attendance, ${ }^{13}$ and indirectly relates this to known differences in current levels of religiosity and attendance between religious groups. The decennial censuses in Northern Ireland confirm that high proportions of the population report a formal religious affiliation, ${ }^{14}$ and analysis of social surveys contemporaneous with the 2001 census shows that church attendance was highest among Catholics, with 67\% attending at least once a week compared with $29 \%$ for mainstream Protestants and $49 \%$ for the more conservative and evangelical
Christians. ${ }^{15}$ On the other hand, conservative Christians are more likely to describe themselves as extremely or very religious and to express a deeper belief in the afterlife and a greater salience of religion in their life, with higher levels of conservatism towards sexual behaviours and the role of women in the family. Therefore, if, as suggested by Durkheim, religious affiliation offers protection against suicide then risk should be highest among those with no religion. Similarly, if resilience accrued through the increased social capital associated with church attendance is the mediating factor, then suicide risk should correlate with the known patterns of church attendance in Northern Ireland - with the lowest risk among Catholics and the highest in those with no religious affiliation, with intermediate levels for mainstream Protestants and conservative Christians. However, if religiosity and its relevance in personal life are of greater consequence, then suicide risk should be more closely aligned with patterns of religiosity, i.e. lowest for more conservative Christian faiths in comparison with Catholics and mainstream Protestants.

\section{Method}

The Northern Ireland Mortality Study (NIMS) is a prospective record-linkage study derived from the 2001 census returns for the whole enumerated population to which subsequently registered deaths to 2009 have been linked. Details of NIMS and linkage processes are described elsewhere. ${ }^{16}$ These data were anonymised, held in a safe setting by the Northern Ireland Statistics and Research Agency (NISRA) and made available to the research team for this study. The use of the NIMS for research was approved by the Office for Research Ethics Committees Northern Ireland.

For this study a cohort of 1106146 adults aged 16-74 years not living in an institutional setting were selected. All the cohort 
attributes were derived from the census record and included on the basis of their known association with risk of suicide. In addition to the usual demographic factors of age (divided into 10 -year age groups), gender and marital status, an indicator of living alone and four indicators of socioeconomic status were included: household car access (two or more cars, one car, no car); education attainment level (no formal qualification, intermediate level, degree level); occupational social class derived using the National Statistics Socio-economic Classification (seven categories); ${ }^{17}$ and housing tenure (owner occupation, private renting, social renting). An additional indicator defining population density, based on the NISRA classification of settlements, ${ }^{18}$ was included to allow adjustment for the generally higher mortality levels associated with urban residence. ${ }^{19,20}$ A three-fold classification was derived: urban, intermediate and rural, representing settlements of more than 75000 persons, 2500-75 000 persons and fewer than 2500 persons respectively.

\section{Religious affiliation}

The assignment of religious affiliation was determined by the responses to two questions in the 2001 census. The first asked whether respondents regarded themselves as belonging to any particular religion: if the answer was 'yes' the second question asked them to specify the religion. In the classic Durkheim analyses and in the more recent Swiss study three groups of Christian religious affiliation were identified: Roman Catholics, Protestants and those stating no affiliation. The Catholic and unaffiliated groups were retained in our analysis but, based on the previous analyses of social surveys (below) and of mortality risk according to religious affiliation in Northern Ireland, ${ }^{21}$ the Protestant group was divided into two: a larger group comprising the main Protestant denominations such as the Presbyterian Church in Ireland, the Church of Ireland and the Methodist Church in Ireland; and a smaller group of 'conservative Christians' comprising the more fundamentalist groups such as Free Presbyterians, Baptists and Brethren. A small group of people classed as 'other faiths' $(0.3 \%$ of the selected cohort $)$ were excluded from the analysis on the basis of size.

\section{Outcome}

The outcome for analysis was risk of mortality from suicide during the 8.7 years from the 2001 census to the end of 2009 . In keeping with established practice both definite suicide and deaths of undetermined intent were combined to define suicide (ICD-10 codes X60-X84, Y10-Y34, Y87.0). ${ }^{22}$ This reduced the possible effects of misclassification, although sensitivity analyses were also undertaken using only definite cases of suicide, to ensure that any relationships with religious groups were not due to a classification bias.

\section{Statistical analysis}

Age-specific rates were used to estimate the absolute differences between the selected religious groups. Cox proportional hazards models were fitted to explore the sociodemographic characteristics, including religious affiliation and measures of socioeconomic status influencing subsequent mortality risk. Proportional hazards assumptions were graphically checked for each variable. Likelihood ratio statistics were used to test for differences in hazard ratios between categories and trends across categories. Tests for interaction were undertaken to determine whether age or gender modified the relationship between denomination and mortality risk. All analyses were carried out using Stata version 10 for Windows.

\section{Results}

Table 1 shows the distribution and sociodemographic characteristics of the main Christian denominational groups and of those with no religious affiliation at the 2001 census. Protestants composed the largest group (41.6\%), followed by Roman Catholics (39.5\%) and conservative Christians (6.3\%), with $12.6 \%$ stating no religious affiliation. This last group had a younger profile than the population as a whole and consequently a higher proportion who were never married, although they also had a greater proportion who were separated or divorced. They also tended to be better educated, in a managerial or professional occupation and to have access to private transport. Almost half of this group (49.7\%) lived in urban areas, which is 10 percentage points higher than the population average, and probably explains the higher levels of private renting. Those identified as Catholics also had a relatively young profile but tended to be less affluent than the other groups, with higher levels of unemployment and social renting.

A total of 52617 deaths occurred in the cohort during the 8.7 years of follow-up, of which 1119 were by suicide or of undetermined intent. Overall, $74.4 \%$ of suicides were of men and $64.8 \%$ were of people less than 45 years old. Online Table DS1 shows the well-recognised relationship between demographic characteristics and socioeconomic status and risk of suicide. Marriage is protective, and living alone increases the risk (fully adjusted $\mathrm{HR}=1.23$, 95\% CI 1.02-1.49). Strong socioeconomic gradients were present, with each of the indicators making an independent contribution to risk. Being unemployed was associated with an increased risk but with wide confidence intervals ( $\mathrm{HR}=1.26,95 \% \mathrm{CI} 0.96-1.66)$. Those with permanent illness were over three times more likely than an employed person to complete suicide ( $\mathrm{HR}=3.14,95 \% \mathrm{CI} 2.64-3.74)$. There was no variation between urban and rural residence. The models, adjusted for age and gender, show that suicide was about $20 \%$ less likely among Protestants than Catholics, although after adjustment for socioeconomic status this difference disappeared $(\mathrm{HR}=0.94$, 95\% CI 0.83-1.08). The risk for those with no religious affiliation was the same as that for Catholics and this was not significantly altered by adjustment for other sociodemographic factors. The lowest risk of suicide was among those in the conservative Christian group, who in the fully adjusted models were about $30 \%$ less likely to complete suicide ( $\mathrm{HR}=0.71$, 95\% CI $0.52-$ 0.97 ). Sensitivity analysis using only definite suicide as the end-point revealed a similar picture (full results available from the authors), again with no significant difference between Catholics and Protestants or those with no religion, but a lower risk among conservative Christians compared with Catholics (HR $=0.72$, 95\% CI 0.52-0.99).

Further analysis showed that the relationship between religious affiliation and mortality risk varied according to age $\left(\chi^{2}=25.2, P=0.047\right)$ but not gender $\left(\chi^{2}=3.72, P=0.294\right)$, so the analyses were split using three age bands: younger adults (aged 16-34 years), middle-aged (35-54 years) and older adults (55-74 years). Table 3 shows the absolute differences in suicide rates for specific age groups: among those aged $16-34$ and 35-54 years Catholics recorded higher rates than either of the Protestant groups, although (marginally) the lowest rates in the eldest age group; the conservative Christian group recorded the lowest rates in the two younger age groups (9.2 and $6.5 v .15 .1$ and 16.7 respectively) but marginally higher rates in the eldest group; and finally, with the exception of the youngest age group, the mainstream Protestant group recorded rates similar to those for Catholics.

Table 4 shows the hazard ratios from fully adjusted Cox proportional hazards models stratified by age group. These mirror 


\begin{tabular}{|c|c|c|c|c|c|}
\hline & Roman Catholic & Protestant & Conservative Christian & No religion & Total \\
\hline Group size, $n$ & 436973 & 459892 & 69500 & 139781 & 1106146 \\
\hline \multicolumn{6}{|l|}{ Age, $\%^{a}$} \\
\hline 16-34 years & 41.5 & 31.9 & 35.2 & 41.7 & 37.1 \\
\hline $35-64$ years & 37.7 & 37.7 & 38.5 & 40.9 & 38.2 \\
\hline $65-74$ years & 20.8 & 30.4 & 26.4 & 17.5 & 24.7 \\
\hline Gender, \% female & 52.5 & 52.2 & 53.1 & 45.3 & 51.5 \\
\hline \multicolumn{6}{|l|}{ Marital status, \% } \\
\hline Married & 53.8 & 62.9 & 66.6 & 54.6 & 58.5 \\
\hline Never married & 35.6 & 25.4 & 24.6 & 32.5 & 30.3 \\
\hline Separated, divorced & 6.8 & 6.8 & 5.2 & 10.0 & 7.1 \\
\hline Widowed & 3.8 & 4.9 & 3.6 & 2.9 & 4.1 \\
\hline \multicolumn{6}{|l|}{ Single-person household } \\
\hline Yes, \% & 8.8 & 11.1 & 9.2 & 14.7 & 10.5 \\
\hline \multicolumn{6}{|l|}{ Academic qualifications, \% } \\
\hline Degree level & 15.5 & 14.0 & 17.8 & 21.2 & 15.7 \\
\hline Intermediate & 42.4 & 41.0 & 44.2 & 45.7 & 42.3 \\
\hline None & 42.1 & 45.1 & 38.0 & 33.2 & 42.0 \\
\hline \multicolumn{6}{|l|}{ Social class, \% } \\
\hline Managerial, professional & 23.1 & 25.5 & 29.9 & 30.0 & 25.4 \\
\hline Intermediate & 9.2 & 12.6 & 12.9 & 11.6 & 11.1 \\
\hline Own account & 9.0 & 8.9 & 9.8 & 7.6 & 8.8 \\
\hline Low supervisory & 8.1 & 9.7 & 8.1 & 8.8 & 8.9 \\
\hline Routine & 32.8 & 32.9 & 28.9 & 27.7 & 32.0 \\
\hline Never worked & 8.4 & 4.5 & 3.3 & 6.6 & 6.2 \\
\hline Student & 9.4 & 5.9 & 7.0 & 7.7 & 7.6 \\
\hline \multicolumn{6}{|l|}{ Housing tenure, \% } \\
\hline Owner & 75.4 & 80.4 & 79.6 & 71.1 & 77.2 \\
\hline Private rent & 6.8 & 5.3 & 9.3 & 11.5 & 6.9 \\
\hline Social rent & 17.8 & 14.3 & 11.2 & 17.4 & 15.9 \\
\hline \multicolumn{6}{|l|}{ Car availability, \% } \\
\hline No car & 38.6 & 45.2 & 48.9 & 37.3 & 41.8 \\
\hline One car & 43.3 & 41.1 & 40.9 & 43.5 & 42.3 \\
\hline Two or more & 18.1 & 13.7 & 10.2 & 19.3 & 15.9 \\
\hline \multicolumn{6}{|l|}{ Area of residence, $\%$} \\
\hline Urban & 35.6 & 39.9 & 40.2 & 49.7 & 39.5 \\
\hline Intermediate & 34.4 & 33.3 & 32.5 & 31.5 & 33.4 \\
\hline Rural & 30.0 & 26.9 & 27.3 & 18.8 & 27.1 \\
\hline
\end{tabular}

\begin{tabular}{|c|c|c|c|}
\hline & \multicolumn{3}{|c|}{ Hazard ratio $(95 \% \mathrm{Cl})$} \\
\hline & Model 1 & Model 2 & Model 3 \\
\hline \multicolumn{4}{|l|}{ Religion } \\
\hline Roman Catholic & 1.00 & 1.00 & 1.00 \\
\hline Protestant & $0.82(0.72-0.93)$ & $0.83(0.73-0.95)$ & $0.94(0.83-1.08)$ \\
\hline Conservative Christian & $0.57(0.42-0.78)$ & $0.60(0.44-0.82)$ & $0.71(0.52-0.97)$ \\
\hline No religion & $0.98(0.82-1.16)$ & $0.91(0.77-1.09)$ & $1.00(0.84-1.20)$ \\
\hline
\end{tabular}

the results of Table 3: at younger ages suicide risk is highest for Catholics; for Protestants and conservative Christians it is about $25 \%$ lower. The risk for those without a religious affiliation is a little lower than that for Catholics but not significantly so. Between the ages of 35 and 54 years there is no appreciable difference between Catholics, Protestants and those with no religion, but the risk for conservative Christians is $50 \%$ lower than that for Catholics ( $\mathrm{HR}=0.50,95 \% \mathrm{CI} 0.29-0.85)$. At older ages, all other groups appear to have a higher suicide risk than Catholics, although none is significant at the 5\% level. Further analysis comparing Catholic and non-Catholic groups confirms that this is not a case of small numbers ( $\mathrm{HR}=1.26,95 \% \mathrm{CI} 0.91-1.75)$.

\section{Discussion}

In this study suicide risk was generally the same for those with and without a professed religious affiliation. Within the denomination groups tested, the risk for younger Catholics was about 20\% higher than for mainstream Protestant denominations, and only those belonging to the more conservative Christian groups recorded lower relative risks (at least up to age 55 years). No difference between men and women was recorded, and the findings are not due to coding differences at the death registration because the same pattern was found for definitive suicide (where suicide 


\begin{tabular}{|c|c|c|c|}
\hline & $\begin{array}{c}\text { Age } \\
\text { 16-34 years }\end{array}$ & $\begin{array}{c}\text { Age } \\
\text { 35-54 years }\end{array}$ & $\begin{array}{c}\text { Age } \\
55-74 \text { years }\end{array}$ \\
\hline $\begin{array}{l}\text { Suicides } \\
\text { in group, } n\end{array}$ & 423 & 518 & 178 \\
\hline Suicide rate $(95 \% \mathrm{Cl})$ & & & \\
\hline $\begin{array}{l}\text { Roman Catholic } \\
\text { Protestant } \\
\text { Conservative }\end{array}$ & $\begin{array}{l}15.1(13.2-17.2) \\
10.1(8.5-12.1)\end{array}$ & $\begin{array}{l}16.7(14.6-19.0) \\
14.8(12.9-17.0)\end{array}$ & $\begin{array}{l}7.4(5.7-9.7) \\
8.0(6.5-9.8)\end{array}$ \\
\hline Christian & $9.2(5.8-14.6)$ & $6.5(3.9-11.1)$ & $8.2(4.6-14.4)$ \\
\hline No religion & $14.4(11.3-18.3)$ & $17.3(13.9-21.5)$ & $11.8(7.8-17.7)$ \\
\hline
\end{tabular}

Table 4 Risk of suicide according to denominational

affiliation stratified according to age

\begin{tabular}{|llll|} 
& \multicolumn{3}{c}{ Hazard ratio $(95 \% \mathrm{Cl})^{\mathrm{a}}$} \\
\cline { 2 - 4 } & \multicolumn{1}{c}{ Age } & \multicolumn{1}{c|}{ Age } & \multicolumn{1}{c|}{ Age } \\
Affiliation & $16-34$ years & \multicolumn{1}{c}{ 35-54 years } & \multicolumn{1}{c|}{$55-74$ years } \\
\hline $\begin{array}{l}\text { Roman Catholic } \\
\text { Protestant }\end{array}$ & 1.00 & 1.00 & 1.00 \\
Conservative & $0.73(0.58-0.92)$ & $1.04(0.86-1.26)$ & $1.22(0.87-1.73)$ \\
Christian & $0.75(0.46-1.21)$ & $0.50(0.29-0.85)$ & $1.31(0.90-2.46)$ \\
No religion & $0.88(0.67-1.17)$ & $1.01(0.78-1.32)$ & $1.41(0.86-2.32)$ \\
a. Hazard ratios from separate models fully adjusted for all covariates in Table DS1. \\
\hline
\end{tabular}

intent was clear). This implies that the relationship between religious affiliation and suicide risk established by Durkheim in the 19th century, along with his explanatory mechanisms, may not pertain in Northern Ireland. Specifically, in this study a particular religious affiliation does not confer any additional resilience to either Catholics or mainstream Protestants - risks associated with these groups are similar to those professing no religious affiliation, and the lower suicide risk associated with the more conservative Christians is unlikely to be due to church attendance per se as their levels of attendance are generally lower than those of Catholics, calthough it was not possible to measure directly the relationship between church attendance and suicide risk in this study.

The absence of a protective effect of religious affiliation in more recent times may be due to an increasing difference between affiliation and non-organisational aspects of religiosity, aligned with a shift in the age distribution of suicide from older to younger people. At the time Durkheim was writing the suicide risk in most of the countries studied increased progressively with age, and we can be reasonably certain that there was a close correspondence between affiliation and church attendance, religious observance and belief. However, dramatically declining church attendance rates and the slower decline in affiliation rates indicates that this correspondence has weakened in modern societies. ${ }^{23}$ That this change has been more evident in younger people is important, ${ }^{24}$ given the marked shift in suicide mortality from old to younger ages in recent decades. ${ }^{25-27}$ At the same time, the rise in 'individualised' religiosity has blurred the differences in religiosity between those affiliated and those non-affiliated. ${ }^{28}$ There are now increasing numbers of people who, despite having rejected institutionalised religion, have not rejected belief in a deity - a philosophy of 'believing without belonging. ${ }^{29,30}$ Analysis of social surveys contemporaneous with the 2001 census shows that about $36 \%$ of those in Northern Ireland who do not belong to an organised religion 'know' or 'feel' that God exists. ${ }^{15}$ Although this should narrow the distinction between affiliated and non-affiliated cohort members, there is some evidence that people with a spiritual dimension to life but without a religious framework may be vulnerable to poor mental health. ${ }^{31}$
Why conservative Christians should have a lower suicide risk is less clear. The results of our study would argue against Durkheim's mechanism of church attendance, as contemporaneous social surveys suggest that church attendance is generally higher among those who are Catholics. However, it is possible that other churchrelated activities or the less organisational aspects of religion are important. It is also possible that the effects of religion might be more indirect and operate through reduction of other social and behavioural factors that are known to increase the risk of suicide. More recently, McCullough \& Willoughby proposed that it is religion's influence on self-control (known to be associated with greater satisfaction and success across many facets in life) that provides the underlying mechanisms explaining its wide array of positive individual and societal effects. ${ }^{32}$ For example, it is recognised that religion can influence lifestyle through endorsement of health-promoting behaviours and disapproval of excess risktaking, and religious involvement is associated with less delinquency, alcohol misuse and drug-taking. ${ }^{31,33,34}$ Religious youths demonstrate greater commitment to studies and higher educational attainment, ${ }^{35}$ and married religious people record higher levels of marital satisfaction and lower levels of divorce. ${ }^{36}$ The conservative Christians in Northern Ireland demonstrate many of these attributes and previous studies here have also demonstrated significantly lower mortality risk from either tobacco or alcohol-related causes, ${ }^{21}$ so their lower risk-taking behaviour could explain the lower suicide risk among younger and middle-aged adults.

\section{Comparison with other studies}

The only other recent census-based study to examine the relationship between religious affiliation and suicide is from Switzerland: this examined suicide risk over 6 years of follow-up among citizens enumerated at the 2000 census. They reported findings in line with Durkheim (suicide risk was 27\% lower in Protestants and $49 \%$ lower in Catholics compared with those with no religious affiliation), although the protective effects of religion were more evident in older people and stronger for women than for men. ${ }^{4}$ Why the studies have produced such different results is unclear, although it should be noted that the overall rate was higher in Switzerland than in Northern Ireland and that risk increased with age, being highest in those aged 85-94 years. However, we would suggest that Switzerland is the anomaly, given its more secularised society and very low levels of church attendance. ${ }^{10}$ Indeed, other Swiss researchers have questioned whether religious affiliation still reflects belonging to a church, and suggest that it better understood in terms of customs and traditions. ${ }^{12}$ If, as our study suggests, religious affiliation is reflecting other facets of society that are more fundamentally linked to suicide risk, this would be in keeping with the meta- analysis of 147 studies by Smith \& McCullough, which found only a very weak negative correlation between religious belief and depression. ${ }^{37}$

\section{Strengths and limitations}

This study has significant strengths and limitations. Its strengths are that it relates to the entire population rather than selected subgroups and that cause of death was derived from validated records. Religious affiliation was measured at the outset of the study and goes some way to obviating the reverse causation that others have proposed as an alternative explanation for the associations between religiosity and poor health outcomes. ${ }^{38}$ Although the census allows good adjustment for most of the individual, household and socioeconomic factors that have been associated with suicide risk, the length of follow-up may raise concerns about the contemporaneousness of some of the characteristics. The main caveat, however, relates to the label of 
affiliation and its relationship with other facets of religiosity that were not available in this census-based study. An overview of studies in this area demonstrates a general trade-off between the breadth of population coverage and the depth of questions asked. At one extreme are census-based studies that provide populationwide coverage and are of sufficient size to generate robust estimates of risk for relatively rare events such as suicide, but the pressure and cost of space on census forms allow little depth to subject area beyond religious affiliation. At the other extreme are dedicated studies that enable a more detailed exploration of the importance and meaning of religion in a person's life, but they often raise issues of representativeness and are rarely of sufficient size to study completed suicide as an end-point. By relating the reported attendance rates and other attributes of belief from contemporaneous social studies to the religious affiliation findings in census, this study goes further than others in this area to bridge these extremes.

\section{Implications of the study}

This large, population-based record linkage study set in Northern Ireland, where there are high levels of professed religious affiliation and church attendance, shows that those with no religious affiliation have a risk of suicide that is no higher than that of Roman Catholics or those belonging to mainstream Protestant faiths, and that among younger adults the risk is highest for Catholics. These findings run counter to the perceived relationship between religion and suicide but may be related to the increasing dissociation between religious affiliation and religious salience, especially among younger adults in whom suicide rates are highest.

\footnotetext{
Dermot O'Reilly, MD, Centre for Public Health, Queen's University, Belfast; Michael Rosato, PhD, Bamford Centre for Mental Health and Wellbeing, Ulster University, Derry, Northern Ireland, UK

Correspondence: Dermot O'Reilly, Health and Social Care Research Unit, Mulhouse Building, Royal Group of Hospitals, Grosvenor Road, Belfast BT12 6BJ, UK. Email: d.oreilly@qub.ac.uk

First received 5 Mar 2014, final revision 11 Apr 2014, accepted 26 Sep 2014
}

\section{Funding}

The Northern Ireland Mortality Study is funded by the Health and Social Care Research and Development Division of the Public Health Agency and the Northern Ireland Statistics and Research Agency (NISRA). The Northern Ireland Longitudinal Study (NILS) Research Support Unit is funded by the Economic and Social Research Council and the Northern Ireland Government. The authors alone are responsible for the interpretation of the data and any views or opinions presented are solely those of the authors and do not necessarily represent those of NISRA or NILS.

\section{Acknowledgements}

The help provided by the staff of the Northern Ireland Mortality Study and the Northern Ireland Longitudinal Study Research Support Unit is acknowledged.

\section{References}

1 Durkheim E. On Suicide (1897), tr. R. Buss. Penguin, 2006

2 Stack S, Lester D. The effect of religion on suicide ideation. Soc Psychiatry Psychiatr Epidemiol 1991; 26: 168-70.

3 Neeleman J, Halpern D, Leon D, Lewis G. Tolerance of suicide, religion, and suicide rates: an ecological and individual study in 19 Western countries. Psychol Med 1997; 27: 1165-71.

4 Spoerri A, Zwahlen M, Bopp M, Gutzwiller F, Egger M. Religion and assisted and non-assisted suicide in Switzerland: National Cohort Study. Int J Epidemiol 2010; 39: 1486-94.

5 Maselko J, Hughes C, Cheyney R. Religious social capital: its measurement and utility in the study of the social determinants of health. Soc Sci Med 2011; 73: 759-67.

6 Gearing R, Lizardi D. Religion and suicide. J Relig Health 2009; 48: 332-41.

7 Dervic K, Oquendo M, Grunebaum M, Ellis S, Burke A, Mann J. Religious affiliation and suicide attempt Am J Psychiatry 2004; 161: 2303-8.

8 Norris P, Inglehart R. Sacred and Secular: Religion and Politics Worldwide. Cambridge University Press, 2004.
9 Voye L. Secularization in a context of advanced modernity. Sociol Relig 1999; 60: 275-88.

10 Bovay C. L'évolution de l'appartenance religieuse et confessionnelle en Suisse (The Evolution of Religious and Confessional Affiliation in Switzerland). Office Fédéral de la Statistique, 2004.

11 Campiche RJ. Les deux visages de la religion: Fascination et désenchantement (The Two Faces of Religion: Fascination and Disenchantment). Labor et Fides, 2004.

12 Nicolet S, Tresch A. Changing religiosity, changing politics? The influence of 'belonging' and 'believing' on political attitudes in Switzerland. Politics Relig 2009; 2: 76-99.

13 Brierley P. UK Christian Handbook, Religious Trends No. 5: Future of the Church. Rosemary Pugh Books, 2005.

14 Macourt M. Counting the People of God: The Census of the Population and the Church of Ireland. Church of Ireland Publishing, 2008.

15 Brewer J. Are there any Christians in Northern Ireland? In Social Attitudes in Northern Ireland: The Eighth Report (eds A Gray, K Lloyd, P Devine, G Robinson, D Heenan): 22-38. Pluto Press, 2002.

16 O'Reilly D, Rosato M, Johnston F, Catney, G, Brolly M. Cohort description: the Northern Ireland Longitudinal Study (NILS). Int J Epidemiol 2012; 41: 634-41.

17 Rose D, Pevalin D, eds. A Researcher's Guide to the National Statistics Socioeconomic Classification. Sage, 2002.

18 Northern Ireland Statistics and Research Agency. Report of the Interdepartmental Urban-Rural Definition Group: Statistical Classification and Delineation of Settlements. NISRA, 2005.

19 O'Reilly G, O'Reilly D, Connolly S, Rosato M. Urban and rural variations in morbidity and mortality in Northern Ireland. BMC Public Health 2007; 7: 123.

20 Connolly S, O'Reilly D, Rosato M, Cardwell C. Area of residence and alcoholrelated mortality risk: a five-year follow-up study. Addiction 2011; 106: 84-92.

21 O'Reilly D, Rosato M. Religion affiliation and health in Northern Ireland: beyond Catholic and Protestant. Soc Sci Med 2008; 66: 1637-45.

22 World Health Organization. The ICD-10 Classification of Mental and Behavioural Disorders: Clinical Descriptions and Diagnostic Guidelines. WHO, 1992.

23 Ashworth J, Farthing I. Churchgoing in the UK: A Research Report from Tearfund on Church Attendance in the UK. Tearfund, 2007.

24 Voas D. The rise and fall of fuzzy fidelity in Europe. Eur Sociol Rev 2009; 25: 155-68.

25 Boyle $P$, Exeter D, Feng Z, Flowerdew R. Suicide gap among young adults in Scotland: population study. BMJ 2005; 330: 175-6.

26 Gunnell D, Middleton N, Whitley E, Dorling D, Frankel S. Why are suicide rates rising in young men but falling in the elderly? A time-series analysis of trends in England and Wales 1950-1998. Soc Sci Med 2003; 57: 595-611.

27 Wasserman D, Cheng Q, Jiang G. Global suicide rates among young people aged 15-19. World Psychiatry 2005; 4: 114-20.

28 Pollack D, Pickel G. Religious individualism or secularism? Testing hypotheses of religious change - the case of Eastern and Western Germany. Br J Sociol 2007; 58: 603-32.

29 Davie G. Religion in Britain Since 1945: Believing Without Belonging. Blackwell, 1994.

30 Davie G. Religion in Modern Europe. OUP, 2000.

31 King M, Marston L, McManus S, Brugha T, Meltzer H, Bebbington P. Religion, spirituality and mental health: results from a national study of English households. Br J Psychiatry 2013; 202: 68-73.

32 McCullough M, Willoughby B. Religion, self-regulation, and self-control: associations, explanations, and implications. Psychol Bull 2009; 135: 69-93.

33 Baier C, Wright B. If you love me, keep my commandments: a meta-analysis of the effect of religion on crime. J Res Crime Deling 2001; 38: 3-21.

34 Michalak L, Triocki K, Bond J. Religion and alcohol in the US National Alcohol Survey: how important is religion for abstention and drinking? Drug Alcohol Depend 2007; 87: 268-80.

35 Jeynes WH. A meta-analysis of the effects of attending religious schools and religiosity on Black and Hispanic academic achievement. Educ Urban Soc 2002; 35: 27-49.

36 Mahoney A, Pargament KI, Tarakeshwar N, Swank AB. Religion in the home in the 1980s and 1990s: a meta-analytic review and conceptual analysis of links between religion, marriage, and parenting. J Fam Psychol 2001; 15 559-96.

37 Smith TB, McCullough ME. Religiousness and depression: evidence for a main effect and the moderating influence of stressful life events. Psychol Bull 2003; 129: 614-36.

38 Maselko J, Hayward D, Hanlon A, Buka S, Meador K. Religious service attendance and major depression: a case of reverse causality? Am J Epidemiol 2012; 175: 576-83. 